\title{
1 A small RNA controls bacterial resistance to gentamicin during iron starvation
}

2 Short title: RyhB promotes resistance to gentamicin

3

4 Sylvia Chareyre ${ }^{1}$, Frédéric Barras ${ }^{1,2}$ and Pierre Mandin ${ }^{1 *}$

$6 \quad 1$ : Aix Marseille Univ - CNRS, Laboratoire de Chimie Bactérienne, Institut de

7 Microbiologie de la Méditéranée, 31 chemin Joseph Aiguier, 13009 Marseille,

8 France

$9 \quad 2$ : Departement de Microbiologie, Institut Pasteur, 28 rue du Dr Roux, 75015 Paris, France pmandin@imm.cnrs.fr complexes 
Phenotypic resistance describes a bacterial population that becomes transiently resistant to an antibiotic without requiring a genetic change. We here investigated the role of the small regulatory RNA (sRNA) RyhB, a key contributor to iron homeostasis, in the phenotypic resistance of Escherichia coli to various classes of antibiotics. We found that RyhB induces resistance to gentamicin, an aminoglycoside that targets the ribosome, when iron is scarce. RyhB induced resistance is due to the inhibition of respiratory complexes Nuo and Sdh activities. These complexes, which contain numerous Fe-S clusters, are crucial for generating a proton motive force (pmf) that allows gentamicin uptake. RyhB directly represses the expression of nuo and sdh operons by binding to their mRNAs, thereby inhibiting their translation. Indirectly, RyhB also inhibits the maturation of Nuo and Sdh by repressing synthesis of the Isc Fe-S biogenesis machinery. Notably, our study identifies nuo as a new direct RyhB target and shows that respiratory complexes activity levels are predictive of the bacterial sensitivity to gentamicin. Altogether, these results unveil a new role for RyhB in the adaptation to antibiotic stress, an unprecedented consequences of its role in iron starvation stress response. 
Understanding the mechanisms at work behind bacterial antibiotic resistance has become a major health issue in the face of the antibiotics crisis. Here, we show that RyhB, a bacterial small regulatory RNA, induces resistance of Escherichia coli to the antibiotic gentamicin when iron is scarce, an environmental situation prevalent during

43 host-pathogen interactions. This resistance is due to RyhB repression of the synthesis and post-translational maturation of the respiratory complexes Nuo and Sdh. These complexes are crucial in producing the proton motive force that allows uptake of the antibiotics in the cell. Altogether, these data point out to a major role for RyhB in escaping antibacterial action. 
The emergence and spread of bacterial multi-resistance to antibiotics has

become a major health issue in the last decades, urging for the development of new anti-bacterial molecules and for a better understanding of the molecular mechanisms at work behind bacterial resistance $(1,2)$. While acquired resistance mechanisms (acquisition of genes or mutations that confer resistance) have long been the main focus of attention, less is known about "phenotypic" resistance, which is the process in which a bacterial population becomes transiently resistant to an antibiotic without requiring a genetic change (3-5). For instance, this kind of resistance has been associated with specific processes such as stationary growth phase, persistence and metabolic changes, reinforcing the idea that the environment encountered by the pathogen is a key determinant for antibiotic susceptibility (6).

Change in utilization of iron-sulfur (Fe-S) cluster biogenesis machineries in Escherichia coli gives a striking example of phenotypic resistance (7). Fe-S clusters are ubiquitous and ancient cofactors used in a plethora of biological processes, such as metabolism and respiration (8,9). In E. coli, Fe-S clusters are formed and brought to target proteins thanks to two dedicated biogenesis systems: the so called "housekeeping" Isc machinery, which homologs are found in mitochondria of eukaryotic organisms, and the stress-responsive Suf system, in which homologs are found in chloroplasts of plants $(10,11)$. These systems are responsible for the maturation of more than 150 Fe-S cluster containing proteins in E. coli, notably numerous proteins contained in the main respiratory complexes I (Nuo) and II (Sdh) (12-14). Strikingly, it was shown that impairment of the E. coli Isc machinery 
enhances resistance to aminoglycosides, a well-known class of antibiotics that target the ribosome (7). This resistance is due to a deficiency in the maturation of the respiratory complexes in isc mutants, which in turn leads to a decrease in the proton motive force (pmf) that is essential for aminoglycosides uptake (15). Incidentally, it was deduced from these results that the Suf machinery is unable to maturate efficiently the Fe-S cluster containing proteins of the respiratory complexes, although the molecular reason for this still remains unclear. Overall this study predicted that an environmental signal that induces the switch from Isc to Suf should induce a transient resistance to aminoglycosides.

Iron starvation is one signal that decreases the expression of the isc operon encoding the Isc pathway. The small RNA RyhB mediates this regulation.(16). RyhB is one of the most studied sRNAs to date in E. coli (17-19). RyhB is regulated by Fur, the main regulator of Fe-homeostasis in many bacteria and is expressed during iron starvation $(20,21)$. When iron becomes limiting in the medium, RyhB base-pairs and represses the translation of more than 100 mRNA targets that encode for nonessential iron-utilizing proteins, thus engaging an "iron sparing" response and redirecting iron consumption in the cell (19). RyhB was shown to participate in the Isc to Suf transition during iron starvation by binding to the iscRSUA mRNA (16). In this way, it induces the degradation of the 3' part of the mRNA that contains iscSUA, encoding the Isc machinery, while the 5' part that encodes iscR remains stable. IscR is the major regulator of Fe-S clusters homeostasis and is itself a Fe-S cluster protein maturated by Isc (22). Accumulation of IscR in its apo-form has been shown to induce the suf operon (23). By its differential regulation of the isc operon, RyhB thus 
95 leads to the accumulation of apo-IscR that will turn on the expression of the 96 alternative Suf system during iron starvation. Iron homeostasis in particular has been shown to modify the sensitivity of bacteria to a number of antibiotics, although the molecular basis behind this is not always clear (24). Here we asked if the sRNA RyhB could participate in phenotypic resistance to various antibiotics during iron starvation. We found that RyhB is necessary to induce aminoglycoside resistance in low iron conditions. By further

102 investigating the mechanism by which RyhB controls this phenotypic resistance, we 103 show that RyhB controls entry of aminoglycosides in the cell by acting at both the 104 synthesis and the maturation levels of the two pmf-producing respiratory complexes 105 Nuo and Sdh. 


\section{Results}

\section{RyhB is involved in resistance to the aminoglycoside gentamicin}

We first investigated the possible role of RyhB in resistance against different class of antibiotics during iron starvation. To do so, we performed antibiotic killing assays by growing wild type (WT) and ryhB mutant cells in LB medium starved or not for iron using $250 \mu \mathrm{M}$ of dipyridyl (DIP), a strong iron chelator. We chose this concentration of DIP because it is known to induce RyhB and we checked that it did not affect the growth of the cells $(25,26)$. Antibiotics were added when cells reached early exponential phase $\left(O D_{600}=0.2\right)$ and the number of survivors was determined by counting the number of colony forming units (c.f.u) after 3 hours of incubation. Four different major classes of antibiotics were tested: aminoglycosides (gentamicin), $\beta$ lactams (ampicillin), fluoroquinolones (norfloxacin), and tetracycline.

As expected, both WT and ryhB mutant cells were sensitive to the presence of all classes of antibiotics when grown in medium not starved for iron (Fig. 1A to D, left panels). Iron chelation did not protect cells against tetracycline (Fig. 1C). In contrast, adding DIP to the medium induced a protective effect on the WT and ryhB mutant strains for ampicillin and norfloxacin (Fig. 1A-B). The protective effect of iron deprivation for these antibiotics has already been observed and its underlying cause has been greatly debated $(7,24,27,28)$. As cells were protected independently of ryhB, we did not pursue these antibiotics further. In contrast, WT cells were protected against gentamicin when DIP was added to the medium, but this protection effect was lost when cells were mutated for $r y h B$. This result thus suggested that RyhB is 
involved in the protection of bacterial cells against aminoglycosides during iron starvation (Fig. 1D).

To further investigate this phenotype, we performed gentamicin kinetic killing assays by growing WT or ryhB mutant cells in presence of DIP and counting the number of surviving bacteria at different time intervals after addition of the antibiotic. In this experiment, both the WT and $\Delta r y h B$ strains showed the same profile when grown in LB (Fig. 1E). In both cases, the majority of the cells were rapidly killed after $1 \mathrm{~h} 30 \mathrm{~min}$ of incubation with gentamicin (5 logs of killing). Again, addition of DIP to the medium had $a \approx 4 \log$ protective effect against gentamicin on WT cells as early as $1 \mathrm{~h} 30 \mathrm{~min}$ post addition of the antibiotic. Cells then remained mainly resistant to gentamicin during the course of the experiment. In contrast, the ryhB mutant gradually became as sensitive as cells grown in the absence of DIP (see $4 \mathrm{~h} 30 \mathrm{~min}$ time point), although killing kinetics were slightly slower than in presence of iron. Finally, to better characterize the effect of RyhB on gentamycin efficacy during iron starvation, we performed minimum inhibitory concentration assays (MIC) by growing WT and $r y h B$ mutants in presence of increasing concentration of gentamicin, with or without DIP. Growing cells in presence of DIP almost doubled the MIC of the WT cells (from $6 \mu \mathrm{g} / \mathrm{mL}$ in LB to $10 \mu \mathrm{g} / \mathrm{mL}$ in presence of DIP) (Figure S1). In sharp contrast, the protective effect allowed by DIP was completely lost in the ryhB mutant. Altogether, these results indicated that RyhB is needed for the phenotypic resistance of $E$. coli to gentamicin in low iron condition.

\section{The RyhB induced resistance to gentamicin is dependent on Nuo and Sdh}



resistance against this aminoglycoside (7). Entry of aminoglycosides is dependent on the proton motive force (pmf) mainly produced directly by respiratory complex I and indirectly by the respiratory complex II, respectively encoded by the nuo and sdh operon $(12,15,29)$. Thus, one hypothesis was that RyhB induced resistance was due to an inhibitory effect on the activity of these two complexes that would block entry of gentamicin in the cell.

To test this hypothesis we repeated the previous killing assays in a strain deleted for both respiratory complexes $(\Delta n u o \Delta s d h)$. As expected, this mutant was resistant to gentamicin (Fig. 2, left panel) (7). Adding DIP to the medium somewhat increased by 1 log the survival of the nuo sdh mutant, suggesting that pmf might be even more decreased in these conditions. Nevertheless, deleting ryhB from this strain did not increase its sensitivity to gentamicin during iron starvation (Fig. 2, right panel) indicating that the phenotype induced by RyhB was dependent on nuo and sdh. testing the sensitivity of the $\Delta n u o$ and $\Delta s d h$ simple mutants, deleted or not for ryhB (Fig. S2). The nuo simple mutant was almost completely resistant to gentamicin in presence of DIP, whether ryhB was present or not. In contrast, the sdh simple mutant became somewhat more sensitive (1 log) when ryhB was deleted from the chromosome. We conclude from these results that while both complexes are needed for full sensitivity of ryhB mutants to gentamicin, Nuo seems to be slightly more 173 important than Sdh. 
These previous results suggested that RyhB inhibits the activity of both

177 respiratory complexes during iron starvation. To test this, we measured Nuo and Sdh specific enzymatic activities in WT and ryhB mutant strains grown in presence or absence of the iron chelator DIP in the growth medium. Nuo activity was decreased when the WT strain was grown in LB medium depleted for iron (about 4-fold) (Fig. 3A). In contrast, deleting ryhB from the chromosome restored $75 \%$ of Nuo activity in presence of DIP. The same pattern was also observed for Sdh activity (Fig. 3B). Altogether, these results confirm that RyhB represses the activities of both Nuo and Sdh complexes in medium deprived for iron.

\section{RyhB represses nuo and sdh expression}

RyhB inhibition of Sdh and Nuo activities may be due to the repression of the synthesis and / or of the maturation of the complexes. Expression of sdh has already been shown to be repressed by RyhB $(20,30)$. In contrast, although pointed out in global approaches, RyhB regulation of nuo genes expression still awaited investigation (17,31-33).

Using the RNA-fold software (http://unafold.rna.albany.edu), we could predict a base-pairing in between RyhB and the 5' un-translated region of the first gene of operon, nuoA (34). This base-pairing involves 21 nucleotides (nt) of RyhB and includes the ribosome-binding site (RBS) and the start codon of nuoA (Fig. 4A).

Overexpression of $r y h B$ on a plasmid decreased the activity of a $P_{B A D}-n u o A-l a c Z$ fusion of about 4-fold, as compared to cells transformed with an empty vector (Fig. 4B). In addition, the $\mathrm{P}_{\mathrm{BAD}}-n u O A-l a c Z$ activity was decreased by 2 -fold when WT 
cells were treated with DIP. This was in sharp contrast with the isogenic ryhB mutant strain for which activity remained the same in presence or absence of DIP (Fig. 4C).

We then tested the biological relevance of the predicted base-pairing by introducing point mutations in the $\mathrm{P}_{\mathrm{BAD}}-n u o A-l a c Z$ chromosomal fusion, giving rise to the nuoA $A_{\text {mut }}$-lacZ fusion (G86C and C87G; Fig. 4A). In contrast to the WT nuoA-lacZ fusion, RyhB overexpression was no longer able to repress activity of the nuoA $A_{\text {mut }}$ fusion (Fig. 4D). We then introduced compensatory mutations in the pRyhB plasmid that should restore base-pairing to the mutated, but not to the WT, nuo-lacZ fusion,

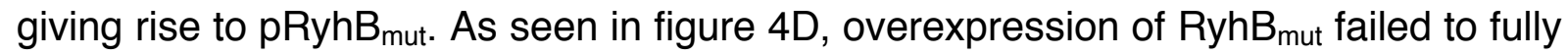
repress the WT nuo-lacZ fusion, but was able to repress nuo $A_{\text {mut }}$-lac $Z$ fusion. Altogether these results show that RyhB represses nuo expression by base-pairing on the mRNA upstream nuoA.

We then evaluated the effect of this repression on protein levels by performing Western blot analyses against NuoG, a protein of the complex. Strikingly, NuoG protein levels decreased steeply, about 3-fold, when the WT strain was grown in presence of DIP (Fig. 4E). This phenotype was suppressed in the ryhB mutant, confirming the in vivo inhibition of Nuo synthesis by RyhB.

As a control and to compare sdh regulation to nuo, we performed a series of similar tests on an sdhC-lacZ fusion. We saw that RyhB overexpression repressed the expression of the fusion by more than 10 fold (Fig. S3A). In addition, the WT fusion was also strongly inhibited when cells were grown in presence of DIP but not when ryhB was deleted from the chromosome (Fig. S3B). Identical conclusions were reached from analyzing SdhB protein levels by performing Western blots (Fig. S3C). These experiments thus confirm the regulation of sdh by RyhB in our conditions. 


\section{RyhB inhibits Nuo and Sdh maturation by repressing iscSUA}

Biogenesis of Fe-S clusters by the Isc machinery has been shown to be key

for full Nuo and Sdh activity and their associated pmf production. The iscSUA mRNA

is a known RyhB target (16). Therefore, we asked if reducing levels of the Isc

machinery synthesis following RyhB inhibition would be sufficiently important such as it would bear consequences on maturation of Nuo and Sdh.

To do so, we measured Nuo and Sdh specific activities in strains deleted for suf or for isc with or without ryhB (Fig. 5). In agreement with the literature, Nuo activity was decreased more than 5 fold in an isc mutant where the Suf machinery alone is responsible for Fe-S biogenesis (Fig. 5A). Activities of the isc mutant remained low in iron-deprived conditions, even when RyhB-mediated repression of Nuo and Sdh respiratory complexes synthesis was alleviated by deleting ryhB. Nuo activity of the $\Delta$ suf strain was comparable to that of the WT and DIP treatment inflicted the same drop in activity. Strikingly however, further deleting ryhB in the suf mutant almost completely restored Nuo activity when cells were grown in low iron condition. Thus, we concluded that repression of iscSUA and nuo by RyhB is sufficient to almost abolish Nuo activity. Moreover, these data strongly suggest that

241 Isc is the only system that allows Fe-S clusters maturation of Nuo complex, regardless of the iron concentration in the medium.

The situation was slightly different for Sdh. Deleting isc severely affected

244 activity of Sdh in presence or absence of iron. In sharp contrast to Nuo however, activity of Sdh was not restored when ryhB was deleted from the suf mutant (Fig. 5B). 
Suf can at least partially maturate Sdh proteins that are produced in absence of ryhB.

These results thus suggest that Isc cannot ensure maturation of Sdh in low iron conditions.

RyhB induces gentamicin resistance by repressing isc, nuo and sdh

\section{expression}

In order to better appraise the role of Fe-S clusters maturation inhibition by

RyhB in the resistance to gentamicin, we performed sensitivity assays in strains

containing only one of the two Fe-S biogenesis machineries. As previously shown,

remained unchanged when DIP was added to the medium, whether RyhB was

present or not (Fig. 6A), thus showing that the slight Sdh activity observed in these

conditions (Fig. 5) is not sufficient to render the cells sensitive to gentamicin. In sharp

contrast, introducing a ryhB mutation restored sensitivity of a suf mutant strain when

grown in presence of DIP (Fig. 6B), which is in agreement with the restoration of Nuo activity in this strain under these conditions.

As Nuo and Sdh activities are determinants for gentamicin sensitivity, we investigated if we could correlate both the levels of complexes enzymatic activity with that of resistance to gentamicin. Strikingly, there was an almost linear correlation between Nuo or Sdh activities of each strain and its sensitivity to gentamicin (Fig. S4

A and B). For instance, strains displaying the lowest Nuo activities were the most resistant to gentamicin, and vice versa.

Taken together, the ensemble of these results show that the maturation of Nuo and Sdh by Isc is essential for pmf production and that RyhB phenotypic resistance to 
bioRxiv preprint doi: https://doi.org/10.1101/451765; this version posted October 24, 2018. The copyright holder for this preprint (which was not certified by peer review) is the author/funder, who has granted bioRxiv a license to display the preprint in perpetuity. It is made available under aCC-BY-ND 4.0 International license.

271 gentamicin is due to both the direct inhibition of the expression of nuo and sdh, but

272 also indirectly to the inhibition of Nuo maturation by Isc. 


\section{Discussion}

Phenotypic resistance can take place when environmental conditions change the metabolic state of the cell. Adaptative molecular responses modify cellular physiology, which induce a transient resistance state. Here, we show that the sRNA RyhB is a major contributor of $E$. coli phenotypic resistance to gentamicin in iron limiting conditions. Aminoglycosides uptake depends upon the activity of respiratory complexes I (Nuo) and II (Sdh) that produce pmf, directly and indirectly, respectively. RyhB acts negatively on both respiratory complexes, directly at the level of their synthesis and indirectly at the level of their maturation (i.e. acquisition of Fe-S clusters) (Fig. 7). Our model strengthens the role of the pmf-producing respiratory complexes in entry of aminoglycosides. Fe-S biogenesis maturation of the complexes was earlier pointed out as the main factor for resistance (7). By identifying here that the nuo mRNA is targeted by RyhB in addition to $s d h$, we show that synthesis of the respiratory complexes is also key in this process.

As early as 2005, the nuo mRNA was suspected to be a target of RyhB as the operon was down-regulated when the sRNA was over-expressed, (17). The nuo mRNA was also more recently found associated with Hfq and RyhB in a global study of sRNA-mRNA interactions (33). We here could predict and confirm a direct basepairing of RyhB to the nuo mRNA at the level of the UTR of nuoA, the first gene of the operon. This base-pairing occurs close to the ribosome binding site of nuoA, which strongly suggests that RyhB represses expression of nuo in a "classical" way, i.e. by occluding binding of the ribosome, leading to the degradation of the mRNA (35). The nuo mRNA is very long (about $15 \mathrm{~kb}$ ) and comprises 14 genes, which makes it one of 
the longest mRNAs regulated by a sRNA to our knowledge. Importantly, in addition to the effects seen on nuoA by our beta-galactosidase assays (Fig. 4), we could also observe by Western blots RyhB repression on NuoG level (Fig. 4E), whose gene lies more than $5 \mathrm{~kb}$ away from the base-pairing site. It will thus be interesting to investigate how far downstream repression inhibits expression of the nuo operon. clusters for Nuo and Sdh in E. coli. Thus, their repression by RyhB is in line with its role in installing an iron sparing response when iron becomes scarce $(17,19)$. Before our results, one could have imagined that RyhB represses Nuo and Sdh expression in order to limit accumulation of inactive apo-complexes in iron scarce conditions. However, both protein levels and activity of Nuo are restored in a ryhB mutant in irondeprived medium indicating that maturation of respiratory complex I is possible under these conditions. These results strongly suggest that RyhB inhibits synthesis of Nuo Sdh not because they cannot be matured, but rather to preclude respiratory complexes to divert iron from other essential processes.

By repressing the iscSUA mRNA expression, RyhB also inhibits indirectly the maturation of Nuo (Fig. 3A and Fig. 5A). In contrast, maturation of Sdh was only partially restored in the ryhB mutant in presence of DIP (Fig. 3B) and, perhaps more surprisingly, this activity did not seem to be dependent on Isc but rather on Suf (Fig. 5B). More investigation is needed to understand the molecular basis for the difference in between Isc and Suf substrates preference. In any case, our results also clearly show that Nuo activity is more important than that of Sdh in installing a phenotypic resistance to gentamicin (Fig. S2). This may relate to pmf production by

321 Nuo and Sdh. Indeed, Nuo, but not Sdh, directly translocates 4 protons across the 
membrane, while both indirectly contribute to pmf production by passing electons to cytochrome oxydase $(12,36)$.

The inhibition of respiratory complexes activity suggests that RyhB controls a complete metabolic shift during iron starvation, likely from respiration to fermentation. Although much needs to be done to assess this hypothesis, our recent survey indicates that a significant number of genes encoding $\mathrm{Fe}-\mathrm{S}$ dependent enzyme of the TCA cycle are under the negative control of RyhB (19). Whether their maturation is also under RyhB influence via its control of the Isc system is an exciting issue to address.

Our study puts RyhB on the focus among a growing number of sRNAs that have been directly or indirectly linked to antibiotic resistance (36-38). However, in most of these cases phenotypes were derived from overexpression of the sRNAs and not relevant to physiological conditions. For instance, 17 out of 26 E. colisRNAs that were assessed in a systematic manner against a variety of antibacterial effectors were shown to affect sensitivity to antibiotics when overexpressed, but few showed any phenotype when mutated (39).

A most spectacular case is represented by the role RyhB could play in the bacterial persistence of uropathogenic $E$. coli to different classes of antibiotics, among which included gentamicin (40). Persistence is a phenomenon in which a fraction of the bacterial population enters a metabolically inactive state that enables it to survive exposure to bactericidal antibiotics (41). Interestingly, in this study it was proposed that $r y h B$ mutants would induce less persister cells because they display increased ATP levels and altered $\mathrm{NAD}^{+} / \mathrm{NADH}$ ratios. In the light of our results, we believe these effects are explained by the fact that $r y h B$ mutants probably display 
higher levels of Nuo, Sdh and Isc and therefore are more metabolically active, but also more prone to uptake the antibiotic. It is noteworthy that these experiments were conducted in rich medium not devoid for iron, and after long treatment with antibiotics (four days), which may explain low induction of RyhB in only a small percentage of bacterial cells that would then be able to resist antibiotics treatment in a persister-like manner.

RyhB homologs and paralogs are found in multiple other bacterial species, which suggests that many bacteria outside of $E$. coli may share the resistance mechanism that we describe here $(19,42-44)$. In particular, other pathogenic bacteria such as Yersinia, Shigella or Salmonella possess not only RyhB homologs, but also the Isc and Suf system and rely on Nuo and Sdh for respiration on oxygen $(45,46)$. RyhB has also been implicated in promoting sensitivity to colicin IA, which is not an antibiotic in a narrow sense, but a bacteriocin secreted by other species to outcompete bacteria sharing the same niches (47). In addition, RyhB has been shown to be involved in the virulence of Shigella dysenteriae by repressing the major virulence regulator $\operatorname{vir} B$, and the sRNA may be associated with the virulence of

362 Yersinia pestis, as the expression of its two RyhB homologs (RyhB1 and RyhB2) 363 increases in the lung of infected mice $(43,48)$. Altogether, these data point out for a 364 major role for RyhB in escaping antibacterial action. 


\section{Materials and methods}

\section{Strains and culture}

All strains used in this study are derivatives of E. coli MG1655 and are listed in

Table S1. Strains were grown in LB broth (Difco), containing various concentrations

for moving marked mutation as described previously in (49). The plac and pRyhB plasmids used in this study are described and have been transformed as previously described in (50). All oligonucleotides used are listed in Table S2.

\section{Antibiotic sensitivity experiments}

Starting from overnight cultures in LB, strains were diluted 1/100 time in fresh medium containing or not DIP and grown aerobically at $37^{\circ} \mathrm{C}$ with shaking until ampicillin: $5 \mu \mathrm{g} / \mathrm{mL}$; tetracycline: $5 \mu \mathrm{g} / \mathrm{mL}$ and norfloxacin: $25 \mathrm{ng} / \mathrm{mL}$ ). After $3 \mathrm{~h}$ cells were taken, diluted in PBS buffer and spotted on LB agar plates and incubated at $37^{\circ} \mathrm{C}$ for $16 \mathrm{~h}$. Cell survival was determined by counting the number of colonyforming units per $\mathrm{mL}$ (c.f.u. $/ \mathrm{mL}$ ). The absolute c.f.u at time-point 0 was of $\approx 5 \times 10^{7}$ cells $/ \mathrm{mL}$ in all experiments.

\section{Minimum inhibitory concentration (MIC) determination}

The MIC were determined as previously described (51). Briefly, each antibiotic 
under aerobic conditions. $\mathrm{OD}_{600}$ for each well was then determined by measuring the absorbance on a Tecan infinite 200. MIC was defined as the lowest drug concentration that exhibited complete inhibition of microbial growth.

\section{Fusions construction}

The $\mathrm{P}_{\mathrm{BAD}}-n u o A-l a c Z$ and $\mathrm{P}_{\mathrm{BAD}}-s d h C$-lacZ fusions were constructed and recombined in PM1205 strain, as previously described (25). Briefly, sequences corresponding to nuo or sdh genes starting from its +1 transcriptional start up to 30 nucleotides downstream of the ATG codon were amplified using oligonucleotides

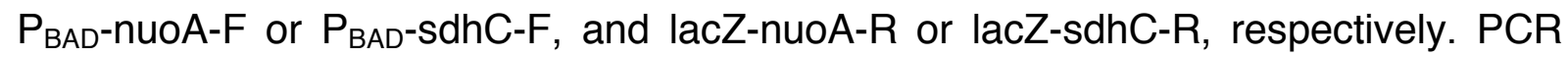
amplifications were carried out using the EconoTaq DNA polymerase from Lucigen. The purified PCR products were then electroporated into strain PM1205 for recombination at the lacZ site. Recombinants carrying the desired fusions (SC005 and SC009) were selected on LB plates devoid of $\mathrm{NaCl}$ and containing $5 \%$ sucrose, $0,2 \%$ arabinose and $40 \mu \mathrm{g} / \mathrm{mL} \quad$ X-Gal (5-bromo-4-chloro-3-indolyl-Dgalactopyranoside). Blue colonies were chosen, and the resulting fusions were sequenced using oligonucleotides lacl-F and Deep-lac.

Overlap PCR was used to introduce point mutation in the fusion. The two PCR products corresponding to the sequence upstream and downstream of the desired mutation were amplified by PCR with oligonucleotides nuoAmut-F and Deep-lac, and Lacl-F and nuoAmut-R containing the desired mutation and using genomic DNA from the SC005 strain as a template. The two PCR products were then joined by an 
overlap PCR using oligonucleotides lacl-F and Deep-lac. The resulting PCR products were purified, electroporated in strain PM1205 and sequenced as described above.

For point mutations in the pRyhB plasmid, the pRyhB plasmid was first purified from a WT $\left(\mathrm{dam}^{+}\right)$E. coli strain, and then amplified by PCR with oligonucleotides RyhBmut-F and RyhBmut-R, containing the desired mutation. The native plasmid was eliminated from the resulting PCR product by Dpn1 enzyme digestion for $1 \mathrm{~h}$ at $37^{\circ} \mathrm{C}$. Plasmids containing the desired mutation were then purified and transformed in SC005 and SC0026 strains.

\section{$\beta$-galactosidase experiments}

Overnight cultures of different strains were diluted 1/100 times in fresh medium in culture flasks containing ampicillin and IPTG (isopropyl B-D1thiogalactopyranoside) or DIP when indicated. After $\approx 7$ hours of growth $100 \mu \mathrm{L}$ of cultures were dispatched in 96 wells microtiter plates (triplicates for each conditions). Absorbance at $600 \mathrm{~nm}$ was measured in a microtiter plate reader (Tecan infinite 200 (B). Then, $50 \mu \mathrm{L}$ of permeabilization buffer were added in each well (100 mM Tris $\mathrm{HCl}$ $\mathrm{pH}$ 7,8; 32 mM Na $2 \mathrm{HPO}_{4} ; 8 \mathrm{mM}$ EDTA; $40 \mathrm{mM}$ Triton; $\mathrm{H}_{2} \mathrm{O}$ milli Q) and the microtiter plate was incubated for 10 minutes at room temperature. O-Nitrophenyl- $\beta$-Dgalactopyranoside (ONPG) was added to the solution and appearance of its degradation product was immediately determined by measuring the absorbance at $420 \mathrm{~nm}$ on a Tecan infinite 200 during 30 minutes. The specific activities were calculated by measuring the Vmax of the $\mathrm{OD}_{420}$ appearance divided by the $\mathrm{OD}_{600}$. Values were then multiplied by 100000 , a coefficient that was chosen empirically to approximate Miller units. 


\section{Nuo and Sdh enzymatic activities}

The Nuo and Sdh enzymatic activities were determined as previously described $(52,53)$. Briefly, overnight cultures of the strains of interest were diluted $1 / 100$ times in fresh LB medium containing or not $250 \mu \mathrm{M}$ of DIP and grown at $37^{\circ} \mathrm{C}$ with shaking until they reached $\mathrm{OD}_{600} \approx 0.6$. Cultures were pelleted by centrifugation $(11000 \mathrm{G}$, $10 \mathrm{~min}$ at $\left.4^{\circ} \mathrm{C}\right)$ and washed in phosphate buffer $(50 \mathrm{mM} \mathrm{pH} \mathrm{7,5).} \mathrm{Cells} \mathrm{were} \mathrm{then}$ lysed at the French press and $100 \mu \mathrm{L}$ were immediately frozen in liquid nitrogen before determining Nuo activity. Nuo enzymatic activity was determined at $30^{\circ} \mathrm{C}$ by monitoring the disappearance of the specific Deamino-NADH (DNADH) substrate at $340 \mathrm{~nm}$ every $5 \mathrm{~s}$ during $10 \mathrm{~min}$ at $30^{\circ} \mathrm{C}$ in a spectrophotometer.

For Sdh activity determination, lysate samples from French press were pellet by centrifugation $\left(11000 \mathrm{G}, 10 \mathrm{~min}\right.$ at $4^{\circ} \mathrm{C}$ ) and the supernatant was used for membrane fraction preparation by ultracentrifugation at $45000 \mathrm{G}$ at $4{ }^{\circ} \mathrm{C}$ during two hours. Pellets were then resuspended in phosphate buffer and kept in liquid nitrogen for later Sdh activity measurements. The enzyme was first activated by incubation in $50 \mathrm{mM}$ Tris- $\mathrm{HCl}(\mathrm{pH} 7.5), 4 \mathrm{mM}$ succinate, $1 \mathrm{mM} \mathrm{KCN}$ for $30 \mathrm{~min}$ at $30{ }^{\circ} \mathrm{C}$. The enzymatic activity was measured in the membrane fraction by monitoring Phenazine EthoSulfate (PES)-coupled reduction of dichlorophenol indophenol (DCPIP) at $455600 \mathrm{~nm}$, in a reaction containing $50 \mathrm{mM}$ Tris- $\mathrm{HCl}(\mathrm{pH} 7.5), 4 \mathrm{mM}$ succinate, 1 $\mathrm{mM}$ KCN, $400 \mu \mathrm{M}$ PES and $50 \mu \mathrm{M}$ DCPIP. 


\section{Quantification of Nuo and Sdh protein levels by Western blot analyses}

461 Total extracts and membranes preparation prepared for Nuo and Sdh activities were

462 used for quantification of Nuo and Sdh protein levels, respectively. Total protein

463 levels were determined by measuring absorbance at $280 \mathrm{~nm}$ on a

464 spectrophotometer. Same amount of total protein level were migrated on poly-

465 acrylamide gels Tris-gly Sodium Dodecyl Sulfate (Novex 4-20 \% Tris-Glycine Mini

466 Gels) then, transferred on nitrocellulose membrane using Pierce G2 Fast Blotter

467 (25 V, 1,3 mA, 7 min). Protein level were detected by incubating the membrane with 468 a-NuoG or a-SdhB (1/1000) antibodies from rabbit and then by an a-rabbit antibody $469(1 / 1000)$ coupled with Hrp peroxidase. Signals were detected by chemiluminescence

470 with Pierce ECL Western blotting system on an ImageQuant LAS 4000 camera.

471 Quantification of protein levels was determined by measuring the specific signal

472 intensity of the bands corresponding to Nuo and Sdh proteins with the ImageJ

473 software. Intensities were normalized using an unspecific band detected by the same 474 antibody. 


\section{Acknowledgements}

477 We would like to thank A. Battesti for precious help with strain constructions and A.

478 Huguenot for critical guidance with enzymatic activities assays. P.M., F.B. and S.C.

479 work was funded by the Centre National de la Recherche Scientifique (CNRS) and

480 Aix Marseille Université (AMU). S.C. is a recipient of a Fondation pour la Recherche

481 Médicale grant (FDT20170436820). 

resistance - state of the evidence. J Glob Health. 2016 Jun;6(1):010306. to effective antimicrobials: a worldwide challenge. Lancet Lond Engl. 2016 Jan

3. van Hoek AHAM, Mevius D, Guerra B, Mullany P, Roberts AP, Aarts HJM. Acquired

Antibiotic Resistance Genes: An Overview. Front Microbiol [Internet]. 2011 Sep 28;2.

Available from: https://www.ncbi.nIm.nih.gov/pmc/articles/PMC3202223/ $18 ; 2(2): 237-55$.

6. Poole K. Bacterial stress responses as determinants of antimicrobial resistance. J

499 cluster biosynthesis controls uptake of aminoglycosides in a ROS-less death pathway. 
$13 ; 460(7257): 831-8$.

12. Simon J, van Spanning RJM, Richardson DJ. The organisation of proton motive and non-proton motive redox loops in prokaryotic respiratory systems. Biochim Biophys Acta. 2008 Dec;1777(12):1480-90.

13. Friedrich T, Dekovic DK, Burschel S. Assembly of the Escherichia coli

NADH:ubiquinone oxidoreductase (respiratory complex I). Biochim Biophys Acta. 2016

14. Lancaster CRD. Succinate:quinone oxidoreductases: an overview. Biochim Biophys

Acta. 2002 Jan 17;1553(1-2):1-6.

521 degradation of the polycistronic mRNA iscRSUA. EMBO J. 2009 Jun 3;28(11):1551-61.

522 17. Massé E, Vanderpool CK, Gottesman S. Effect of RyhB small RNA on global iron use in 
18. Massé E, Salvail H, Desnoyers G, Arguin M. Small RNAs controlling iron metabolism. Curr Opin Microbiol. 2007 Apr;10(2):140-5.

19. Chareyre S, Mandin P. Bacterial Iron Homeostasis Regulation by sRNAs. Microbiol Spectr. 2018 Mar;6(2).

20. Massé E, Gottesman S. A small RNA regulates the expression of genes involved in iron metabolism in Escherichia coli. Proc Natl Acad Sci U S A. 2002 Apr 2;99(7):4620-5.

21. Seo SW, Kim D, Latif H, O’Brien EJ, Szubin R, Palsson BO. Deciphering Fur transcriptional regulatory network highlights its complex role beyond iron metabolism in Escherichia coli. Nat Commun. 2014 Sep 15;5:4910.

22. Giel JL, Nesbit AD, Mettert EL, Fleischhacker AS, Wanta BT, Kiley PJ. Regulation of iron-sulphur cluster homeostasis through transcriptional control of the Isc pathway by [2Fe2S]-IscR in Escherichia coli. Mol Microbiol. 2013 Feb;87(3):478-92.

23. Mettert EL, Kiley PJ. Coordinate Regulation of the Suf and Isc Fe-S Cluster Biogenesis Pathways by IscR Is Essential for Viability of Escherichia coli. J Bacteriol. 2014 Dec $15 ; 196(24): 4315-23$.

24. Ezraty B, Barras F. The "liaisons dangereuses" between iron and antibiotics. FEMS Microbiol Rev. 2016;40(3):418-35.

25. Mandin P, Chareyre S, Barras F. A Regulatory Circuit Composed of a Transcription Factor, IscR, and a Regulatory RNA, RyhB, Controls Fe-S Cluster Delivery. mBio. 2016 20;7(5).

26. Massé E, Escorcia FE, Gottesman S. Coupled degradation of a small regulatory RNA and its mRNA targets in Escherichia coli. Genes Dev. 2003 Oct 1;17(19):2374-83. 
27. Kohanski MA, Dwyer DJ, Hayete B, Lawrence CA, Collins JJ. A common mechanism of

28. Dwyer DJ, Kohanski MA, Collins JJ. Role of reactive oxygen species in antibiotic action and resistance. Curr Opin Microbiol. 2009 Oct;12(5):482-9.

29. Unden G, Steinmetz PA, Degreif-Dünnwald P. The Aerobic and Anaerobic Respiratory

May;6(1).

30. Desnoyers G, Massé E. Noncanonical repression of translation initiation through small

RNA recruitment of the RNA chaperone Hfq. Genes Dev. 2012 Apr 1;26(7):726-39. 15;6(6):e01947-01915. 2;43(21):10308-20.

Methods Mol Biol Clifton NJ. 2008;453:3-31. 
Resistance in Bacteria and Their Potential Value as Novel Drug Targets. Front Microbiol. 2017;8:803.

38. Felden B, Cattoir V. Bacterial Adaptation to Antibiotics through Regulatory RNAs.

Antimicrob Agents Chemother. 2018 May;62(5).

39. Kim T, Bak G, Lee J, Kim K-S. Systematic analysis of the role of bacterial Hfq-

68.

40. Zhang S, Liu S, Wu N, Yuan Y, Zhang W, Zhang Y. Small Non-coding RNA RyhB

Mediates Persistence to Multiple Antibiotics and Stresses in Uropathogenic Escherichia coli https://www.ncbi.nlm.nih.gov/pmc/articles/PMC5808207/

Shigella dysenteriae virulence. Infect Immun. 2007 Jul;75(7):3470-7. 
587

588

589

590

591

592

593

594

595

596

597

598

599

600

601

602

603

604

605

606

607

44. Kim JN, Kwon YM. Genetic and phenotypic characterization of the RyhB regulon in Salmonella Typhimurium. Microbiol Res. 2013 Jan 15;168(1):41-9.

45. Unden G, Dünnwald P. The Aerobic and Anaerobic Respiratory Chain of Escherichia coli and Salmonella enterica: Enzymes and Energetics. EcoSal Plus. 2008 Sep;3(1).

46. Parkhill J, Wren BW, Thomson NR, Titball RW, Holden MT, Prentice MB, et al. Genome sequence of Yersinia pestis, the causative agent of plague. Nature. 2001 Oct $4 ; 413(6855): 523-7$

47. Salvail H, Caron M-P, Bélanger J, Massé E. Antagonistic functions between the RNA chaperone $\mathrm{Hfq}$ and an SRNA regulate sensitivity to the antibiotic colicin. EMBO J. 2013 Oct $16 ; 32(20): 2764-78$.

48. Broach WH, Egan N, Wing HJ, Payne SM, Murphy ER. VirF-independent regulation of Shigella virB transcription is mediated by the small RNA RyhB. PloS One. 2012;7(6):e38592.

49. C. Manson J. Experiments with Gene Fusions. Edited by T. J. Silhavy, M. L. Berman and L. W. Enquist. Published by Cold Spring Harbor Laboratory, Fulfillment Department, P.O. Box 100, Cold Spring Harbor, New York 11724, U.S.A. 1984. 350 pages. Paperback $\$ 40$ (\$48 outside U.S.). ISBN 087969163 8. Genet Res - GENET RES. 1985 Apr 1;45.

50. Mandin P. Genetic screens to identify bacterial sRNA regulators. Methods Mol Biol Clifton NJ. 2012;905:41-60.

51. Herisse M, Duverger Y, Martin-Verstraete I, Barras F, Ezraty B. Silver potentiates aminoglycoside toxicity by enhancing their uptake. Mol Microbiol. 2017;105(1):115-26.

52. Seaver LC, Imlay JA. Are respiratory enzymes the primary sources of intracellular 
bioRxiv preprint doi: https://doi.org/10.1101/451765; this version posted October 24,2018 . The copyright holder for this preprint (which

was not certified by peer review) is the author/funder, who has granted bioRxiv a license to display the preprint in perpetuity. It is made available under aCC-BY-ND 4.0 International license.

608 hydrogen peroxide? J Biol Chem. 2004 Nov 19;279(47):48742-50.

609 53. Calhoun MW, Gennis RB. Demonstration of separate genetic loci encoding distinct

610 membrane-bound respiratory NADH dehydrogenases in Escherichia coli. J Bacteriol. 1993

611 May;175(10):3013-9.

612 


\section{Figure Legends}

Figure 1. RyhB is involved in gentamicin resistance during iron starvation. A to

D: strains were grown in LB (left panels) or in LB with DIP $(250 \mu \mathrm{M})$ (right panels) for relatively to to and plotted as $\log _{10}$ of surviving bacteria. The absolute c.f.u. at timepoint zero was $\approx 5.10^{7}$ c.f.u. / $\mathrm{mL}$ for each sample. Error bars represent the standard deviations of three independent experiments. Statistical analysis were performed with

Student's T-test: ${ }^{*} p<0.05 ;{ }^{* *} p<0.01 ;{ }^{* *} p<0.001$. E: WT (squares) and ryhB mutant (circles) strains were grown in LB (regular lines) or LB depleted for iron (dashed lines) with (red curves) or without (black curves) gentamicin. The number of c.f.u. was determined at different times. Error bars represent the standard deviations of three independent experiments. Statistical analysis were performed with Student's T-test: ${ }^{*} p<0,05 ;$ N.S.: Not significant.

Figure 2. RyhB induced gentamicin resistance is dependent on Nuo and Sdh. with or without gentamicin $(5 \mu \mathrm{g} / \mathrm{mL})$ in LB (left panels) or in LB with DIP $250 \mu \mathrm{M}$ (right panels). Colony forming units were counted to determine the number of surviving bacteria. Points were normalized relatively to to and plotted as $\log _{10}$ of surviving bacteria. The absolute c.f.u. at time-point zero was $\approx 5.10^{7}$ c.f.u. $/ \mathrm{mL}$ for each sample. Error bars represent the standard deviations of three independent 
experiments. Statistical analysis were performed with Student's T-test: ${ }^{*} p<0,05$; ${ }^{* *} p<0,01$.

Figure 3. RyhB decreases Nuo and Sdh enzymatic activities. A: NADH specific enzymatic activity of Nuo in WT or $\Delta r y h B$ strain grown in LB (dark grey bars) or in LB containing DIP (light grey bars) were determined by following the disappearance of the D-NADH substrate by spectrophotometry ( $\mathrm{nmol} / \mathrm{min} / \mathrm{mg}$ protein). B: Succinate dehydrogenase activities in WT or $\Delta r y h B$ strains grown in LB (dark grey bars) or in LB containing DIP (light grey bars) were determined by following the absorbance of DCPIP ( $\mathrm{nmol} / \mathrm{min} / \mathrm{mg}$ protein). Bars represent the mean of at least three experiments and error bars represent the standard deviations. Statistical analysis were performed with Student's T-test: ${ }^{*} p<0,05 ;{ }^{* *} p<0,01 ;{ }^{* *} p<0,001$.

Figure 4. RyhB represses nuo expression. A: base-pairing predicted between RyhB and nuo mRNA. Nucleotides belonging to $r y h B$ are represented on top, those corresponding to nuo on the bottom. Relative position to the transcriptional start site of $r y h B$ and nuo are indicated above and below the sequences, respectively. B: the SC005 strain containing a $\mathrm{P}_{\mathrm{BAD}}-n u O A-l a c Z$ fusion was transformed with the empty the plac vector or with the pRyhB plasmid containing $r y h B$ under the control of an IPTG inducible promoter. Cells were grown in LB containing ampicillin $(25 \mu \mathrm{g} / \mathrm{mL})$, IPTG $(100 \mu \mathrm{M})$ and arabinose $(0,02 \%)$ during $6 \mathrm{~h}$ after which $B$-galactosidase activity was determined. Specific activities are represented by arbitrary units that were empirically determined to be approximately equivalent to Miller units. Error bars represent the standard deviations of six independent experiments. C: strains containing the $\mathrm{P}_{\mathrm{BAD}^{-}}$ 
nuoA-lacZ fusion, WT (SC005) or deleted for ryhB (SC006) were grown in LB with or without DIP $(200 \mu \mathrm{M})$ during 6h before B-galactosidase activities were measured. Each bar represents the mean from six independent experiments; error bars represent the standard deviations. D: Strains containing either the $\mathrm{P}_{\mathrm{BAD}}-n u o A-l a c Z$ or the $\mathrm{P}_{\mathrm{BAD}}-$ nuo $_{\text {mut }}$-lacZ fusions were transformed with the plac, pRyhB or pRyhBmut plasmids and B-galactosidase activity were determined. Each point represents the mean from six or more experiments. E: WT and ryhB mutant cell extracts from cultures grown in LB or in LB with DIP $(250 \mu \mathrm{M})$ were subjected to immunoblot analyses using antibodies raised against NuoG. Quantification represents the mean of three different experiments.

Figure 5. RyhB inhibits Nuo enzymatic activity by repressing isc. Nuo $(A)$ and Sdh (B) specific enzymatic activities of $\Delta i s c$ and $\Delta s u f$ mutants containing or not $r y h B$ grown in LB (dark grey bars) or in LB containing DIP (light grey bars) were determined. Bars represent the mean of 3 independent experiments and error bars represent the standard deviations. Statistical analysis were performed with Student's T-test: ${ }^{*} p<0,05 ;{ }^{* \star} p<0,01 ;{ }^{* * *} p<0,001 ;$ N.S.: Not significant.

\section{Figure 6. RyhB induces gentamicin resistance by inhibiting Fe-S clusters} maturation. The $\Delta i s c(\mathrm{~A})$ and the $\Delta s u f(\mathrm{~B})$ strains containing or not ryhB were grown with (light grey bar) or without (dark grey bars) gentamicin $(5 \mu \mathrm{g} / \mathrm{mL})$ for $3 \mathrm{~h}$ in LB (left panels) or in LB with DIP $(250 \mu \mathrm{M})$ (right panels). After that, cells were diluted in PBS and spotted on LB agar plates. c.f.u. and $\log _{10}$ of surviving bacteria numbers were 
determined. Error bars represent the standard deviation of three independent experiments. Statistical analysis were performed with Student's T-test: ${ }^{*} p<0,05$; ${ }^{\star \star \star} p<0,001 ;$ N.S. : Not significant.

691 uptake. Gentamicin reaches the ribosome and incudes mistranslation, which renders cannot enter the cytoplasm thus making cells resistant to the antibiotic. 
Figure S1. RyhB increases the resistance to gentamicin during iron starvation. The WT and the $\triangle r y h B$ mutant MIC were determined by growing cells in medium containing various concentrations of gentamicin and the iron chelator DIP $(250 \mu \mathrm{M})$. The MIC was defined as the lowest drug concentration that exhibited complete inhibition of microbial growth

Figure S2. Sensitivity of nuo and sdh simple mutants to gentamicin. Anuo (BEFB05), $\Delta n u o \quad \Delta r y h B$ (SC085), $\Delta s d h$ (BEFB06) and $\Delta s d h \Delta r y h B(\mathrm{SC086})$ strains were grown with or without gentamicin $(5 \mu \mathrm{g} / \mathrm{mL})$ for $3 \mathrm{~h}$ in LB with DIP $200 \mu \mathrm{M}$. Colony forming units were counted to determine the number of surviving bacteria. Points were normalized relatively to to and plotted as $\log _{10}$ of surviving bacteria. The absolute c.f.u. at time-point zero was $\approx 5.10^{7}$ c.f.u. $/ \mathrm{mL}$ for each sample. Error bars represent the standard deviation of three independent experiments. Statistical analysis were performed with Student's T-test: ${ }^{*} p<0,05 ;{ }^{* *} p<0,01$; N.S. : Not significant

Figure S3. RyhB represses sdh expression. A: strain containing a $\mathrm{P}_{\mathrm{BAD}}-\mathrm{sdhC-lacZ}$ fusion (SC009) was transformed with the empty plac vector or with pRyhB plasmid containing ryhB under the control of an IPTG inducible promoter. Cells were grown in LB containing ampicillin $(25 \mu \mathrm{g} / \mathrm{mL})$, IPTG $(100 \mu \mathrm{M})$ and arabinose $(0,02 \%)$ during $6 \mathrm{~h}$ after which B-galactosidase activity was determined. Specific activities are represented by arbitrary units that were empirically determined to approximate Miller units. Error bars represent the standard deviations of six independent experiments. B: strains containing $\mathrm{P}_{\mathrm{BAD}}-\mathrm{SdhC}$-lacZ WT (SC009) or deleted for ryhB (SC010) were 
grown in LB with or without DIP $(200 \mu \mathrm{M})$ during 6h before B-galactosidase activities were measured. Each bar represents the mean from six independent experiments. C:

722 WT and ryhB mutant cell extracts from cultures grown in LB or in LB with DIP $(250 \mu \mathrm{M})$ were subjected to Western blot analyses using antibodies raised against SdhB. Quantification represents the mean of three different experiments.

Figure S4. Gentamicin sensitivity can be directly correlated with Nuo and Sdh specific activities. Sensitivity to gentamicin of WT, $\Delta r y h B, \Delta i s c, \Delta i s c \Delta r y h B, \Delta s u f$ and $\Delta$ suf $\Delta r y h B$ strains grown in LB (black points) or in LB containing DIP (red points) were plotted relatively to their Nuo (A) or Sdh (B) enzymatic activity respectively. The mean line represents linear correlation between the gentamicin sensitivity and

731 complexes activities $A: R^{2}=0,86593 ; B: R^{2}=0,77648$. Error bars represent the 732 standard deviation of three independent experiments.

Table S1. Strains and plasmids used in this study.

Table S2. Oligonucleotides used in this study. 
bioRxiv preprint doi: https://doi.org/10.1101/451765; this version posted October 24,2018 . The copyright holder for this preprint (which was not certified by peer review) is the author/funder, who has granted bioRxiv a license to display the preprint in perpetuity. It is made available under aCC-BY-ND 4.0 International license.

A.

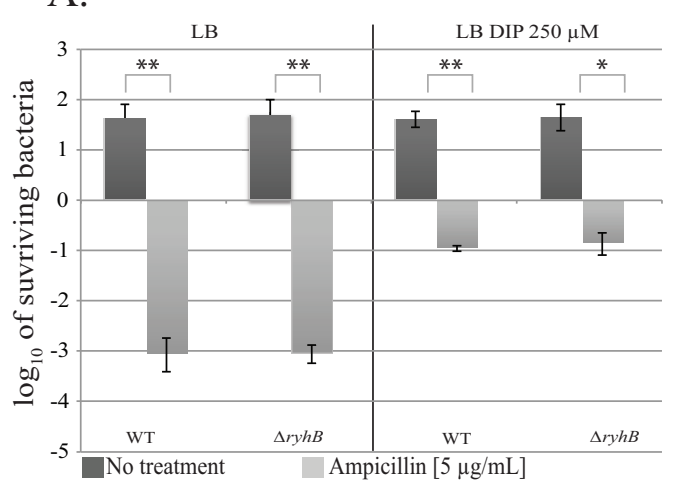

C.

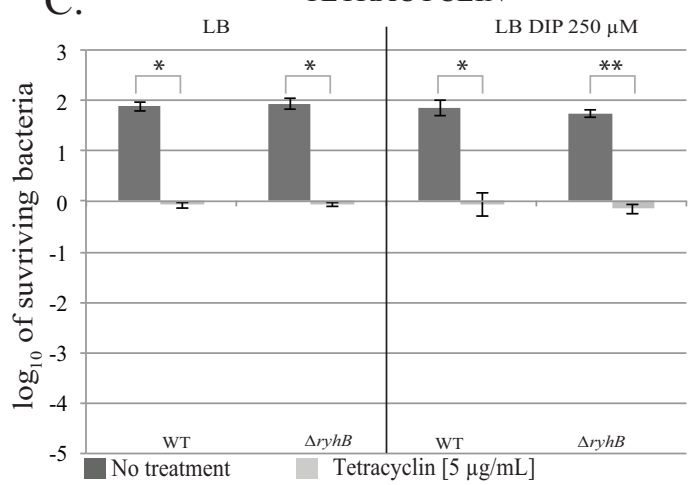

B.

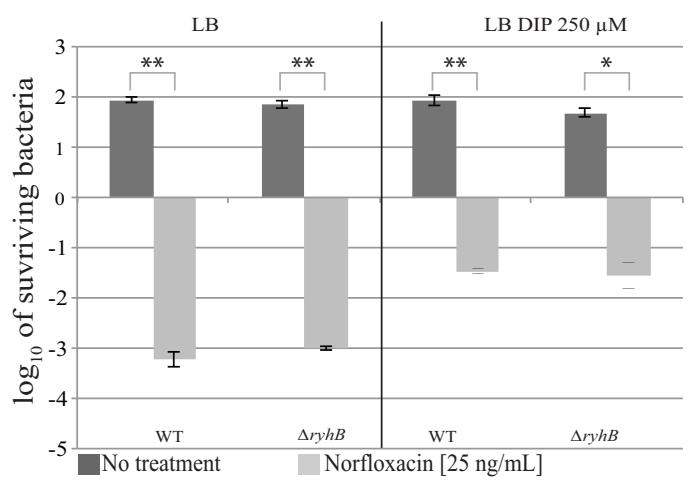

D.

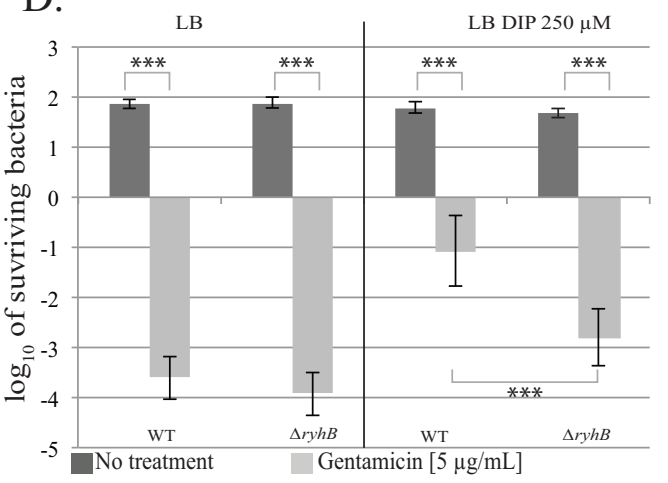

E.

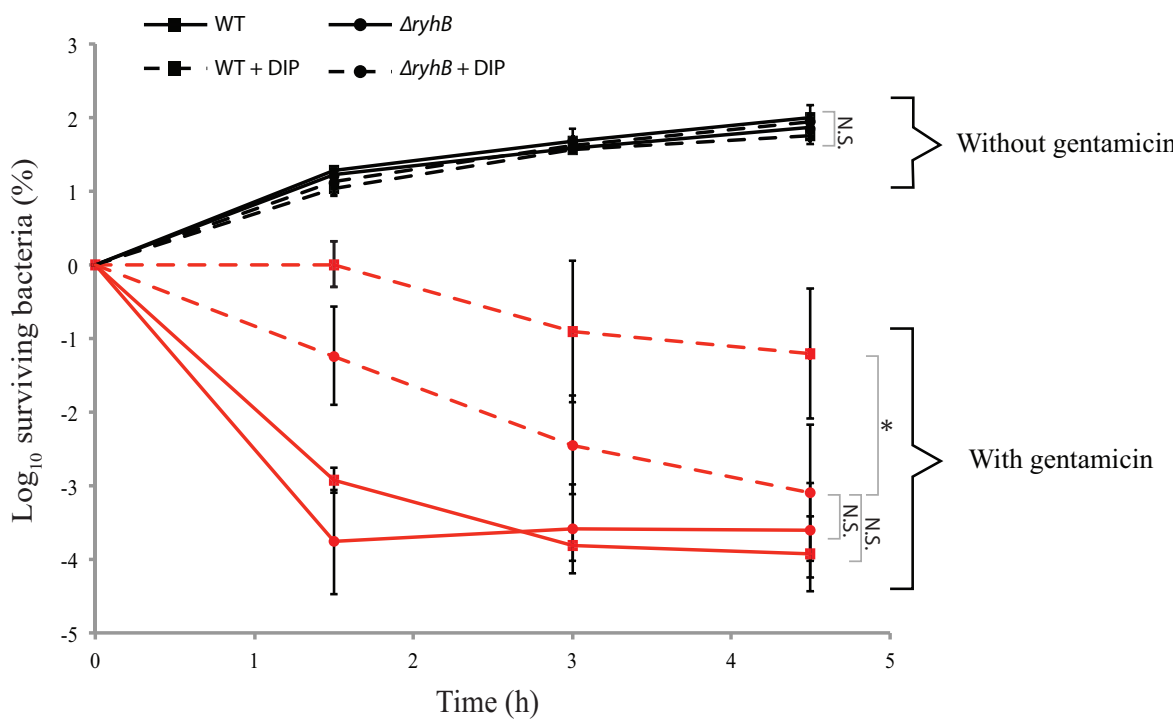

Figure 1. 
bioRxiv preprint doi: https://doi.org/10.1101/451765; this version posted October 24,2018 . The copyright holder for this preprint (which was not certified by peer review) is the author/funder, who has granted bioRxiv a license to display the preprint in perpetuity. It is made available under aCC-BY-ND 4.0 International license.

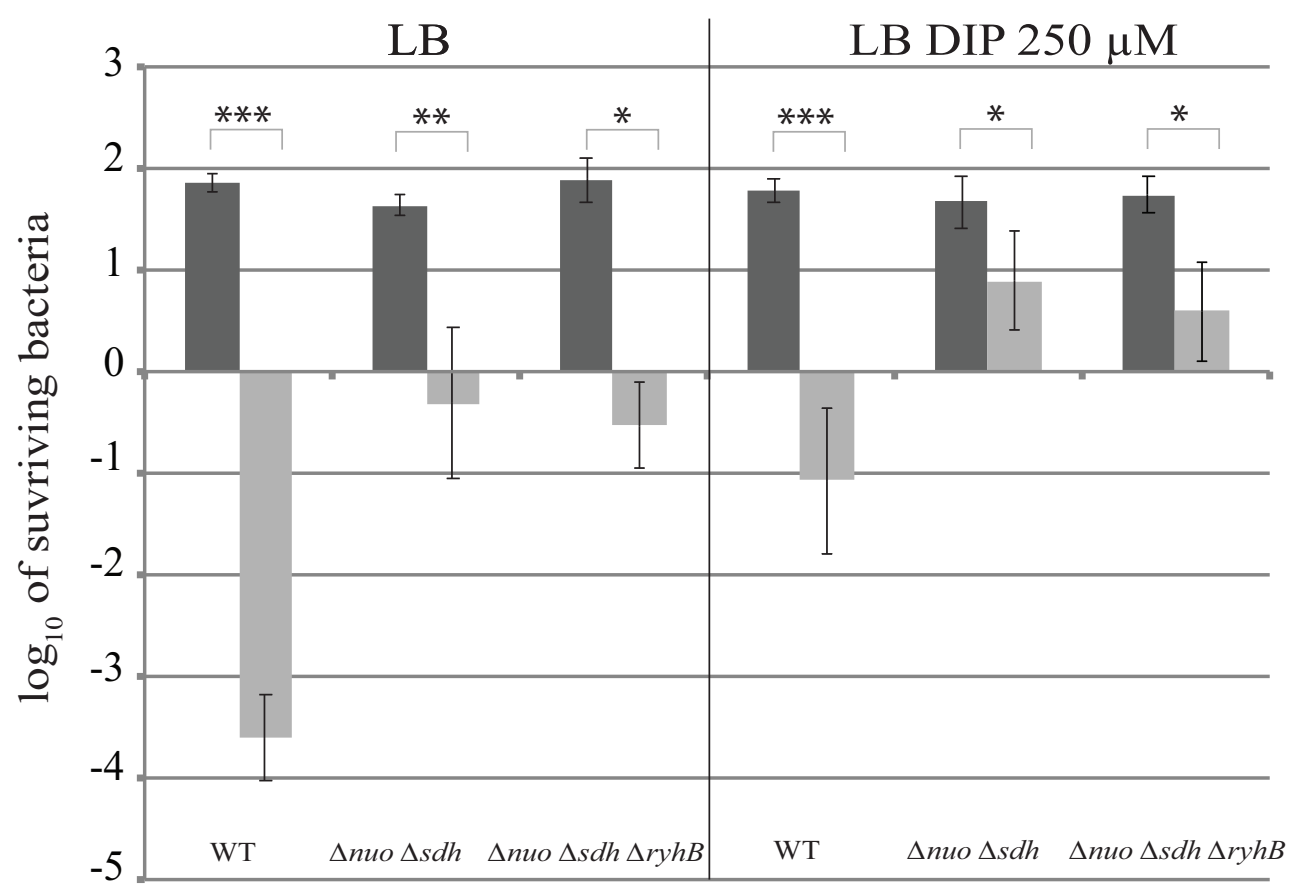

No treatment Gentamicin [5 $\mu \mathrm{g} / \mathrm{mL}]$

Figure 2. 
bioRxiv preprint doi: https://doi.org/10.1101/451765; this version posted October 24,2018 . The copyright holder for this preprint (which was not certified by peer review) is the author/funder, who has granted bioRxiv a license to display the preprint in perpetuity. It is made available under aCC-BY-ND 4.0 International license.

A.

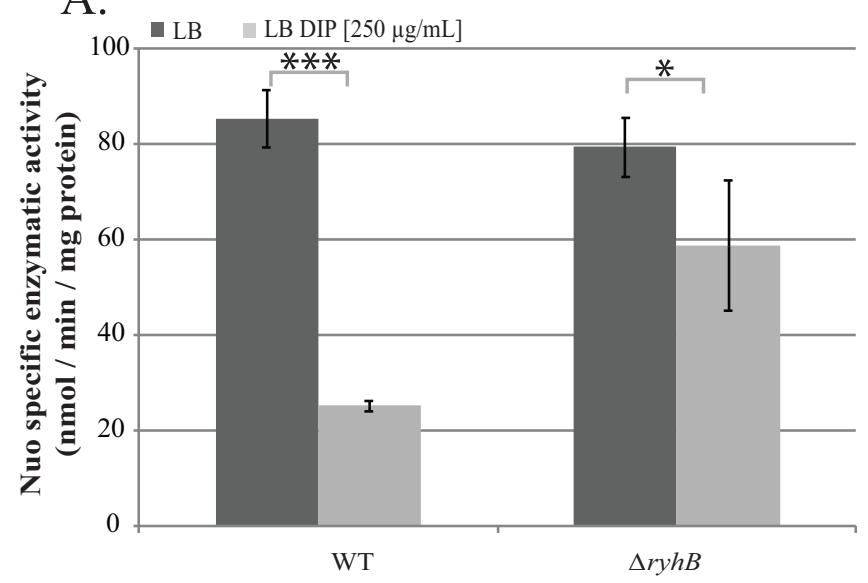

B.

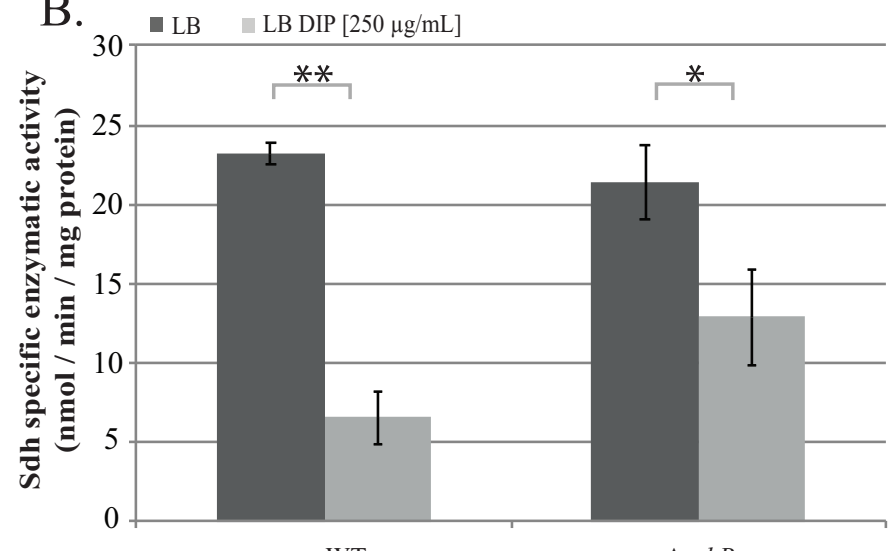

Figure 3. 
bioRxiv preprint doi: https://doi.org/10.1101/451765; this version posted October 24,2018 . The copyright holder for this preprint (which was not certified by peer review) is the author/funder, who has granted bioRxiv a license to display the preprint in perpetuity. It is made available under aCC-BY-ND 4.0 International license.

A.

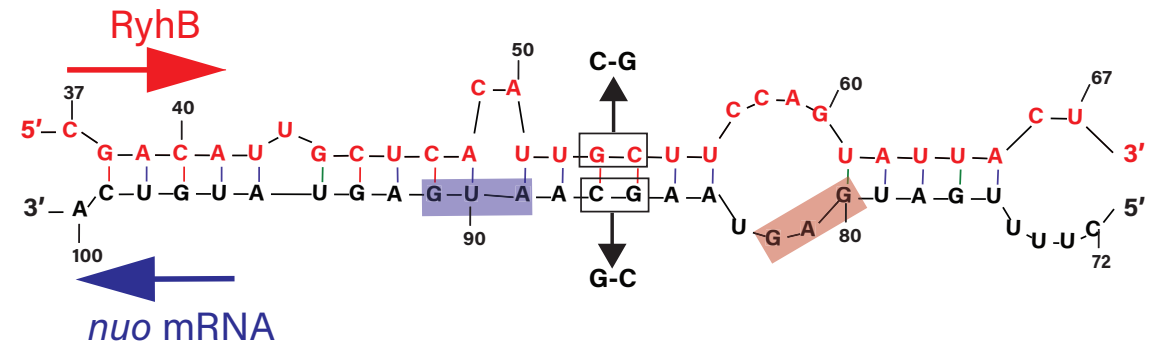

B.

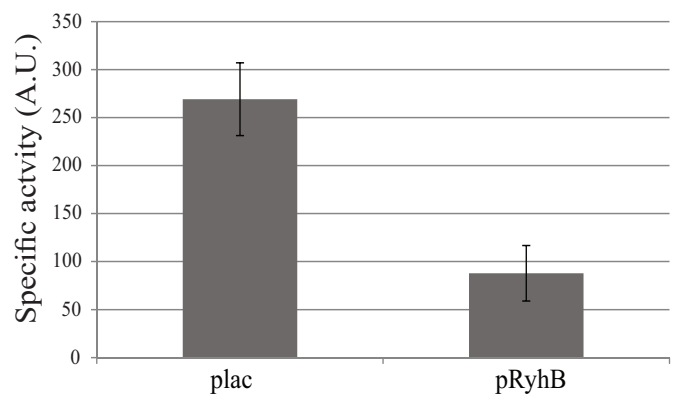

C.
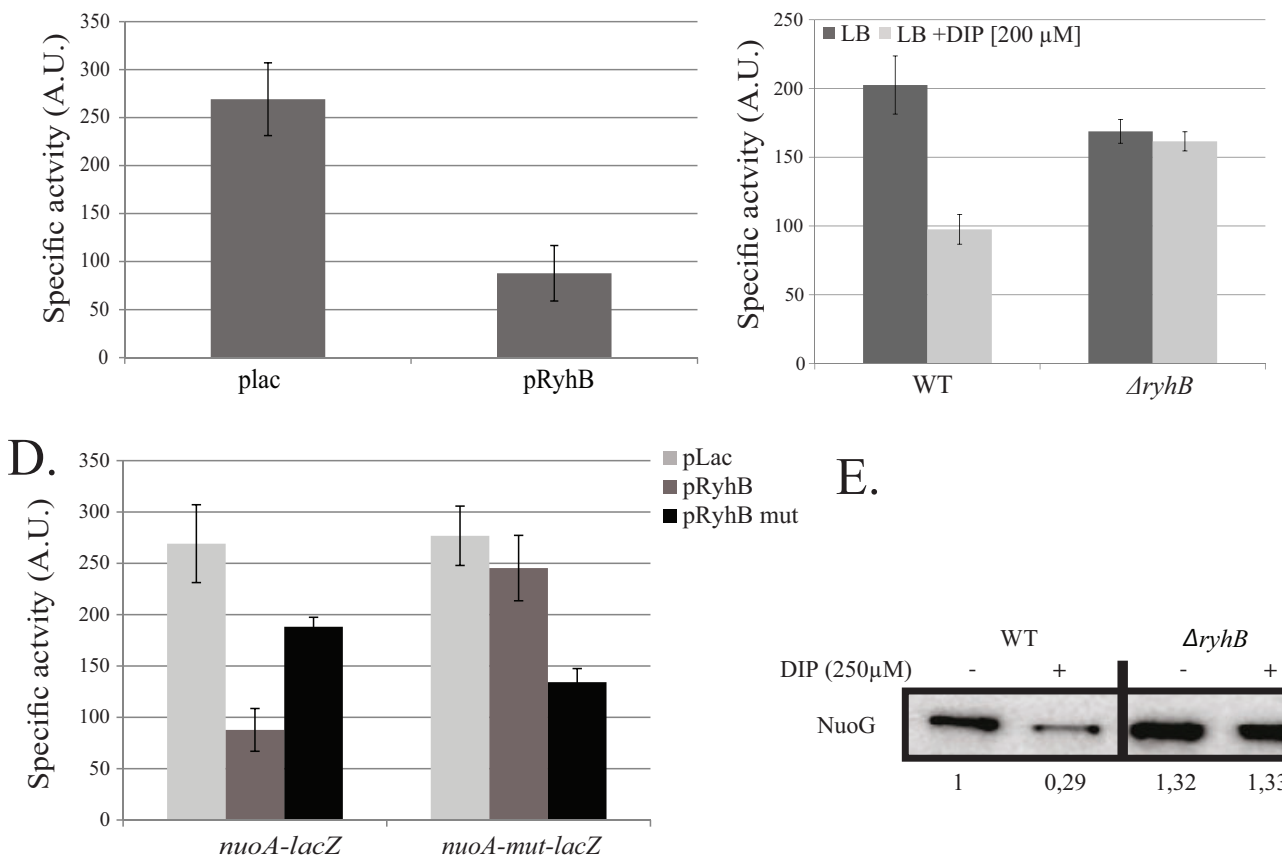

E. $\mathrm{pRyhB}$ - pRyhB mut

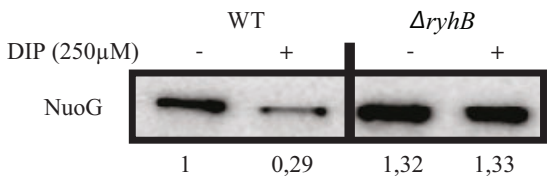

Figure 4. 
bioRxiv preprint doi: https://doi.org/10.1101/451765; this version posted October 24,2018 . The copyright holder for this preprint (which was not certified by peer review) is the author/funder, who has granted bioRxiv a license to display the preprint in perpetuity. It is made available under aCC-BY-ND 4.0 International license.

A.

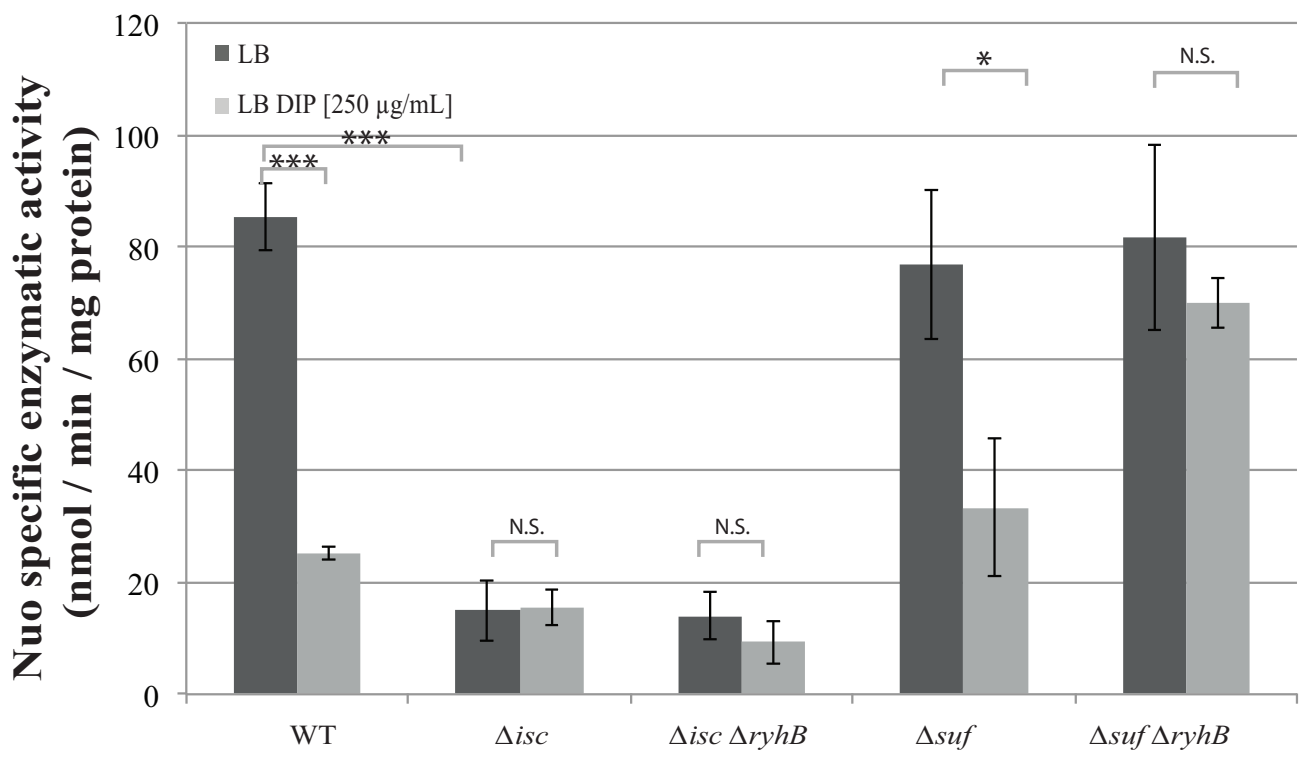

B.

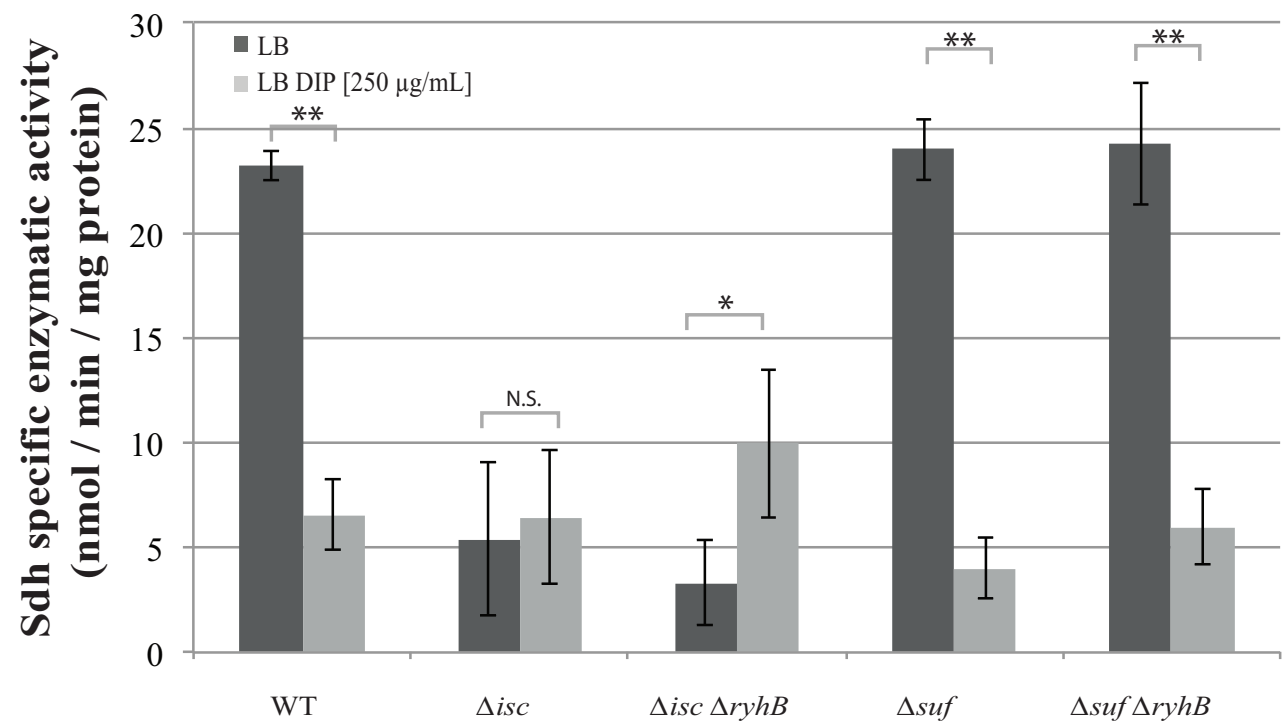

Figure 5. 
bioRxiv preprint doi: https://doi.org/10.1101/451765; this version posted October 24, 2018. The copyright holder for this preprint (which was not certified by peer review) is the author/funder, who has granted bioRxiv a license to display the preprint in perpetuity. It is made available under aCC-BY-ND 4.0 International license.
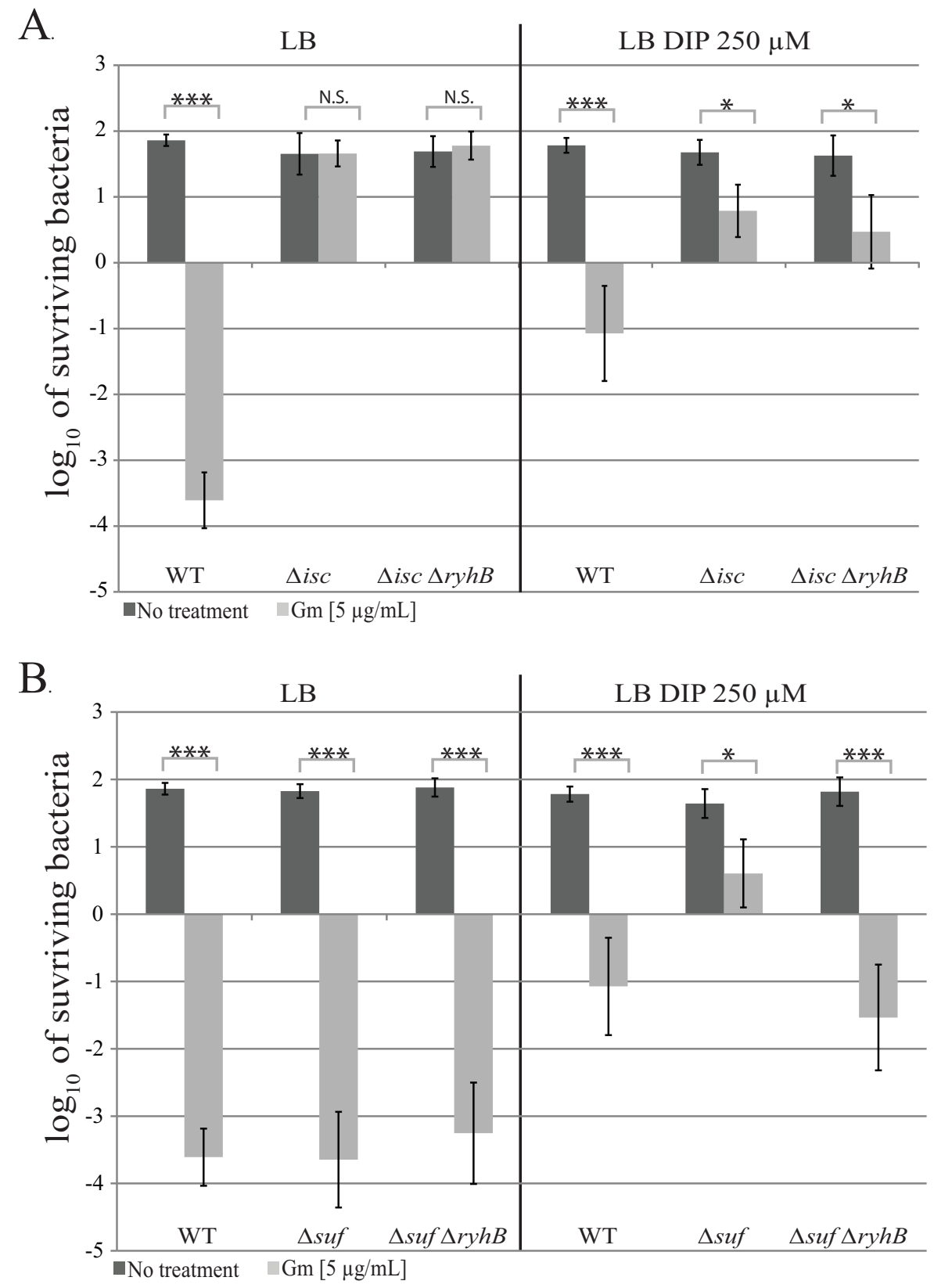
bioRxiv preprint doi: https://doi.org/10.1101/451765; this version posted October 24, 2018. The copyright holder for this preprint (which was not certified by peer review) is the author/funder, who has granted bioRxiv a license to display the preprint in perpetuity. It is made available under aCC-BY-ND 4.0 International license.

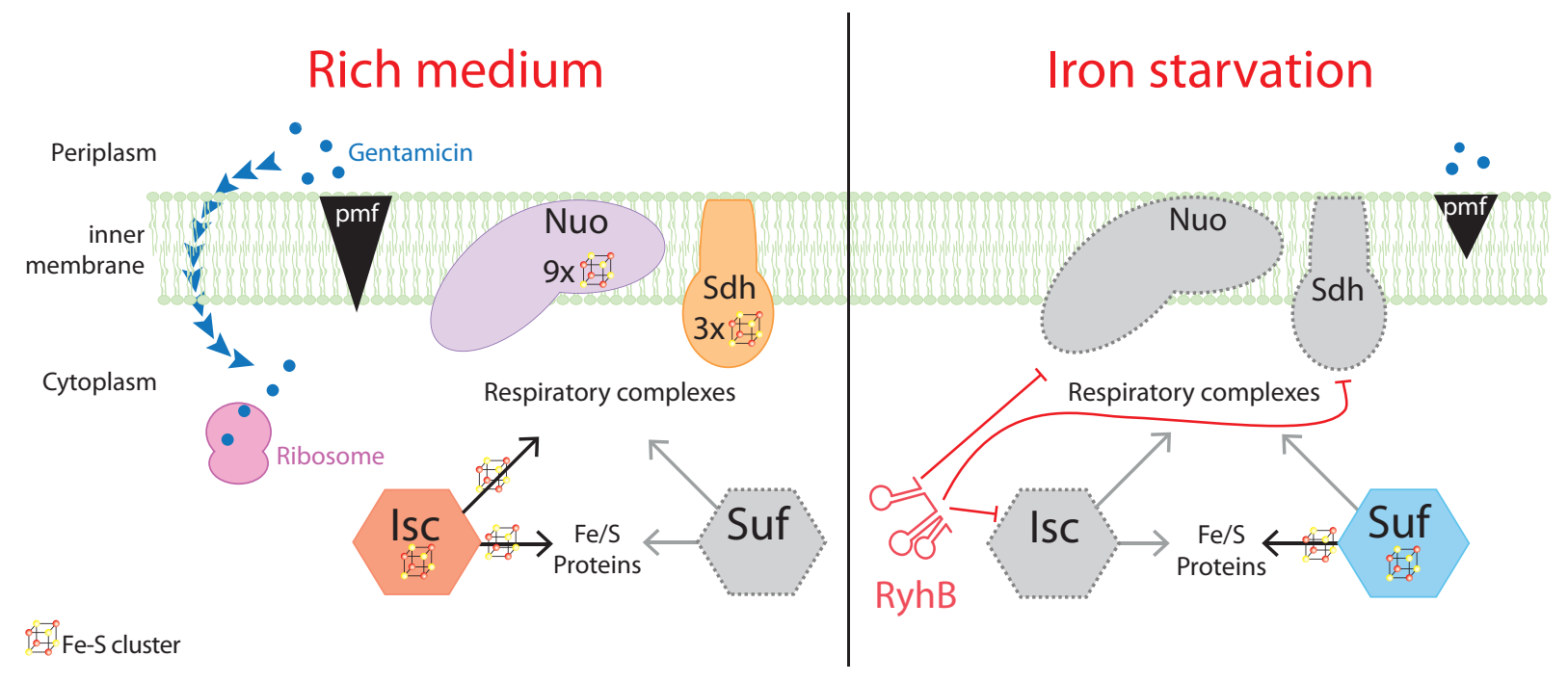

Figure 7. 